\author{
JURNAL EINSTEIN \\ Jurnal Hasil Penelitian Bindang Fisika \\ Available online http://jurnal.unimed.ac.id/2012/index.php/einsten \\ e-issn: $2407-747 x$, p-issn $2338-1981$
}

\title{
KARAKTERISTIK RESPON TIKUS TERHADAP ALAT PENGHASILGELOMBANG ULTRASONIK BERBASIS ARDUINO UNO
}

\author{
Ibrahim dan Abd. Hakim S \\ Jurusan Fisika, Fakultas Matematika dan Ilmu Pengetahuan Alam, Universitas Negeri Medan, \\ Indonesia \\ ibrahim.juntak1@gmail.com \\ Diterima September 2018; Disetujui Oktober 2018; Dipublikasikan November 2018
}

\begin{abstract}
ABSTRAK
Telah dilakukan penelitian yang berjudul karakteristik respon tikus terhadap alat penghasil gelombang ultrasonik berbasis Arduino Uno dengan tujuan untuk mengkarakteristikan respon tikus terhadap frekuensi ultrasonik. Alat tersebut didesain dengan dua bagian pokok perangkat, yakni perangkat lunak dan perangkat keras. Perangkat lunak terdiri dari sistem pemrograman arduino. Prinsip kerja alat diawali dengan memilih frekuensi melalui penekanan push button. Kemudian Arduino Uno akan memproses data dengan sistem PWM (Pulse Width Modullation) dan meneruskannya ke IC 386. Gelombang output yang amplitudonya sudah dikuatkan hingga 200 x penguatan kemudian dipancarkan melalui piezzo super tweeter. Hasil analisis yang diperoleh besar frekuensi yang mampu mempengaruhi tikus adalah $40 \mathrm{KHz}, 50 \mathrm{KHz}$ dan $60 \mathrm{KHz}$ pada jarak 2 meter dengan lama pemaparan selama 10 menit, dan frekuensi efisien untuk mengusik tikus adalah $60 \mathrm{KHz}$.
\end{abstract}

Kata Kunci : Arduino Uno, IC 386, Frekuensi, Tikus

\section{PENDAHULUAN}

Tikus digolongkan kedalam kelas mamalia, ordo Rodensia (hewan yang mengerat), subordo myomorpha, family Muridae, dan subfamily Murinae. Infestasi tikus disuatu tempat dapat diketahui dengan mengamati adanya kotoran, jejak kaki, bekas gigitan dan bau yang khas. Kotoran (fases dan urin) dan gigitan tikus dapat menimbulkan berbagai penyakit yang mematikan pada manusia seperti infeksi hantavirus (demam berdarah), scrub typhus, murine typhus, spotted fever group (SFG), Rickettsiae, pes, leptospirosis, salmonellosis dan meningitis.

Berdasarkan uraian diatas, masalah kesehatan dan kerusakan lingkungan, bila tikus diracun maka akan mengganggu rantai makanan dan keseimbangan ekosistem. Alternatif yang dapat digunakan untuk mengatasi masalah tersebut adalah mengusir tikus dengan metode akustik jenis gelombang ultrasonic.

Tikus memiliki jangkauan pen-dengaran antara 5-60 KHz. Untuk mengusik pendengaran tikus perlu diciptakan alat pembangkit frekuensi ultrasonik dengan frekuensi $40-60 \mathrm{KHz}$.

Alat pembangkit frekuensi ultrasonik akan dirancang menggunakan mikro-kontroler dengan tipe Arduino Uno sebagai sistem kontrol, LCD akan menampilkan nilai frekuensi dan Piezzo Super Tweeter sebagai output gelombang ultrasonik. Setelah diperoleh frekuensi ultrasonik, rangkaian diuji cobakan pada tikus yang berada dalam kotak yang didesain menyerupai persem-bunyian tikus bertujuan untuk mengetahui karakteristik respon tikus terhadap gelom-bang ultrasonik. 
Adapun tujuan dilakukannya pene-litian ini adalah untuk merancang/ menghasilkan alat penghasil gelombang ultrasonik dan mengetahui karakteristik respon tikus terhadap alat ini.

Tikus termasuk familia Muridae dari kelompok mamalia (hewan menyusui). Para ahli zoology (ilmu hewan) sepakat dengan menggolongkannya kedalam ordo Rodensia (hewan yang mengerat), Subordo Myomorpha, family Muridae dan sub family Murinae. Potensi reproduksi tikus sangat tinggi dan ciri yang menarik adalah gigi serinya beradaptasi untuk mengerat (mengerat dan menggigit benda-benda yang keras).

Belum banyak diketahui dan disadari bahwa kelompok hewan ini juga membawa, menyebarkan, dan menularkan berbagai penyakit kepada manusia, hewan, dan ternak peliharaan. Penyakit bersumber rodensia yang disebabkan oleh berbagai agen penyakit seperti virus, rickettsia, bakteri, protozoa, dan cacing dapat ditularkan kepada manusia secara langsung, melalui feses, urin, dan ludah atau gigitan rodensia dan pinjal dan tak langsung, melalui gigitan vector ektoparasit tikus dan mecit (kutu, pinjal, caplak, tungau). Frekuensi pendengaran tikus yaitu dalam range frekuensi $40 \mathrm{~Hz}$ sampai $100 \mathrm{KHz}$, di atas $20 \mathrm{KHz}$ termasuk ultrasonic.

Gelombang ultrasonik merupakan gelom-bang mekanik longitudinal yang frekuensinya di atas $20 \mathrm{KHz}$. Frekuensi ini tidak dapat ditangkap oleh indera pendengar manusia, misalnya getaran yang dihasilkan oleh magnet listrik, getaran kristal piezo-elektrik (karakteristik gelombang ultrasonik yang merambat melalui medium meng-akibatkan getaran partikel). Gelombang bunyi atau yang dikenal sebagai gelombang akustik yaitu gelombang mekanik yang dapat merambat dalam medium zat padat, cair dan gas.

Panjang gelombang dengan frekuensi berbanding terbalik, yaitu frekuensi ultrasonik tinggi memiliki panjang gelom-bang pendek dan sebaliknya. Gelombang ultrasonik memiliki frekuensi yang melebihi batas pendengaran manusia, yaitu lebih besar dari $20 \mathrm{kHz}$. Perangkat ultrasonik dalam dunia medis menggunakan gelombang suara berkisar 1-20 MHz.
Arduino Uno adalah papan pengembangan (development board) yang berbasis mikrokontroler chip ATMega 328P dengan bentuk yang kecil. Secara fungsi tidak ada bedanya dengan Arduino lain. Perbedaan utama terletak pada ketiadaan jack power DC dan penggunaan konektor Mini-B USB.

Disebut sebagai papan pengembangan karena board ini memang berfungsi sebagai arena prototyping sirkuit mikrokontroller. Dengan menggunakan papan pengembangan, anda akan lebih mudah merangkai rangkaian elektronika mikrokontroller dibanding jika anda memulai merakit ATMega 328 dari awal.

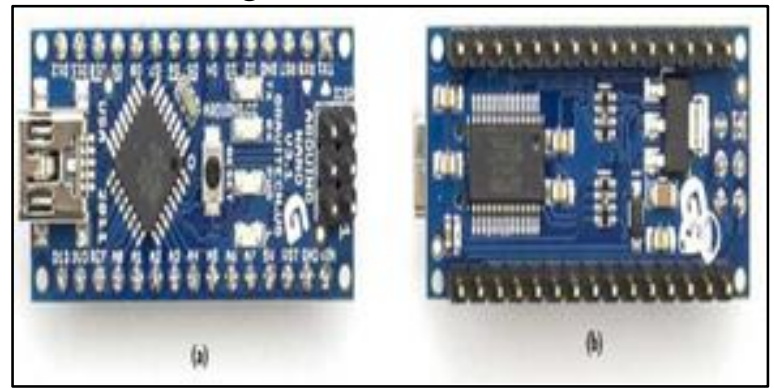

Gambar 1. Papan arduino Uno (a). Tampak atas dan (b). Tampak bawah.

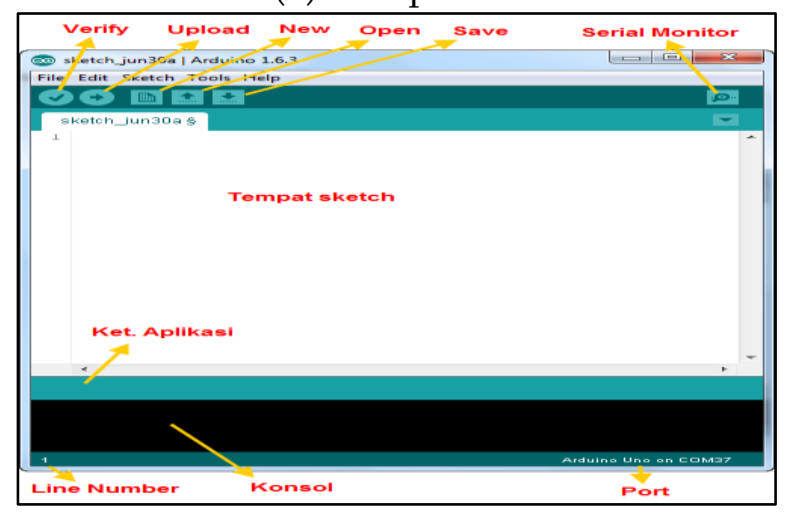

Gambar 2. Interface Arduino IDE

Pada umumnya komponen elektronika memerlukan catu daya DC untuk dapat mengoperasikan rangkaian. Catu daya DC dapat diperolah dari accu, baterai, atau dari sumber daya AC yang disearahkan. Rangkaian catu daya DC yang diperolaeh dari penyearahan tegangan AC disusun dari transformator, penyearah, dan regulator tegangan. Untuk proyek akhir kali ini penulis menggunakan catu daya berupa AC yang disearahkan mengeluarkan tegangan DC.

Resistor adalah suatu komponen elektronika yang dapat menghambat arus listrik. Fungsi resistor dapat digambarkan sebagai sekeping papan yang dipergunakan untuk 
menahan aliran air yang deras di selokan/parit kecil. Dengan memakai tahanan papan ini, maka arus air dapat terhambat alirannya. Makin besar papan yang dipergunakan untuk menahan arit parit, makin kecil air yang mengalir. Begitu pula kejadian ini dapat diterapkan dalam pelajaran elektronika. Makin besar resistansi (tahanan), makin kecil arus listrik dan tegangan yang melaluinya.

LCD adalah suatu display dari bahan cairan kristal yang pengoperasiannya menganut sistem dotmatrix. LCD banyak diaplikasikan untuk alat-alat elektronika seperti kalkulator, laptop, handphone. Komunikasi data yang dipakai menggunakan mode teks, artinya semua informasi yang dikomunikasikan memakai kode ASCII (American Standard Code for Information Interchange).

Huruf dan angka yang akan ditampilkan dalam bentuk kode ASCII, kode ini diterima dan diolah oleh mikroprosesor LCD menjadi titiktitik pada dot matrix yang terbaca sebagai huruf dan angka. Tugas mikrokontroler hanyalah mengirim kode-kode ASCII untuk ditampilkan. LCD yang paling sering digunakan untuk operasi standar mempunyai ukuran lebar display 2 baris 16 kolom atau disebut sebagai LCD Character 16x2. LCD ini mempunyai 16 buah pin konektor, yang secara umum tiap pinnya didefinisikan seperti pada gambar 3 .

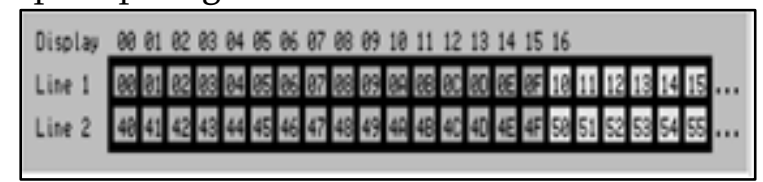

Gambar 3. Susunan alamat pada LCD

\section{METODE PENLITIAN}

Perancangan alat penghasil gelom-bang ultrasonik ini meliputi pemrograman pada Arduino Uno untuk menghasilkan gelombang ultrasonik, tampilan pada LCD dan suara (piezzo super tweeter). Rancangan sistem terdiri dari:

1. Arduino Uno memiliki fungsi sebagai kontrol rangkaian yaitu sebagai pengendali nilai frekuensi dan menampilkan frekuensi pada LCD.

2. LCD berfungsi sebagai penampil frekuensi output yang dihasilkan rangkaian.
3. Piezzo super tweeter berfungsi sebagai pemancar gelombang ultrasonik.

Adapun rangkaian yang akan dirancang adalah seperti yang diperlihatkan pada gambar 4 dibawah ini.

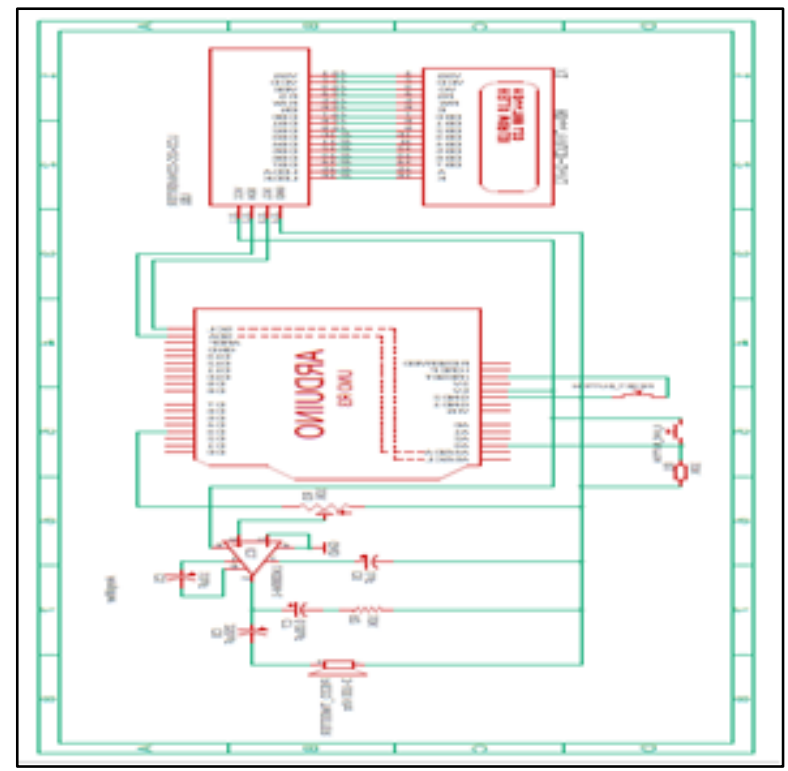

Gambar 4. Rangkaian ultrasonik secara keseluruhan

Metode penelitian yang telah dilakukan dalam merancang alat penghasil gelombang ultrasonik ini adalah :

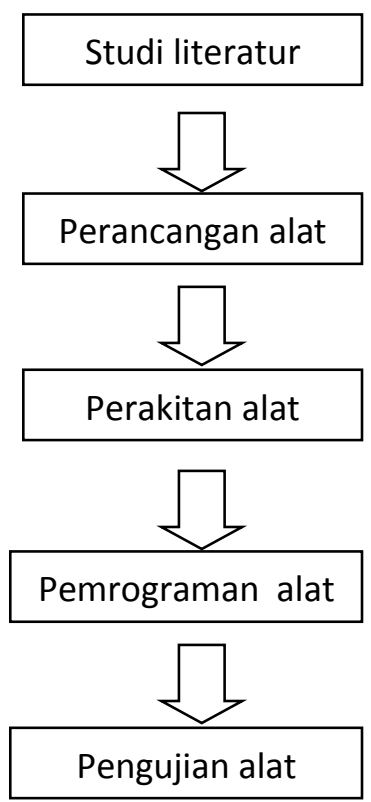




\section{HASIL DAN PEMBAHASAN}

Telah dirancang alat penghasil gelombang ultrasonik berbasis Arduino Uno sebagai sistem pengendali seperti gambar 5 berikut :

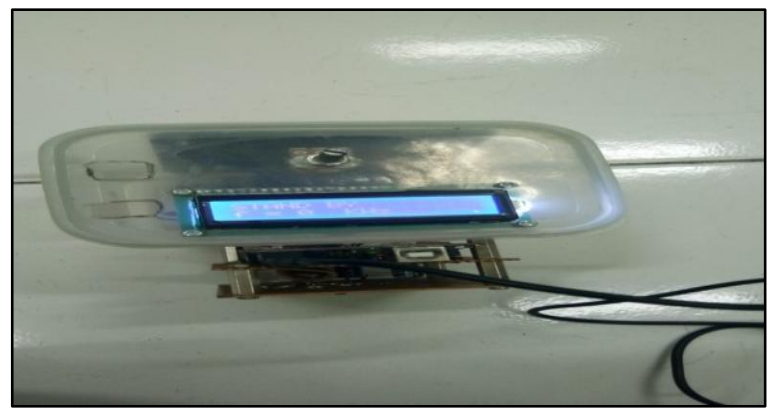

Gambar 5. Alat penghasil gelombang ultrasonik yang telah dirangkai

Sistem kerja alat ini yakni, saat kita mengaktifkan alat dan menekan push button sesuai frekuensi yang kita inginkan, maka mikrokontroler sebagai sistem pengendali akan mengirimkan sinyal berupa gelombang ultrasonik. Kemudian gelombang ultrasonik akan dikuatkan amplitudonya oleh IC LM386. Lalu gelombang ultrasonik tersebut akan dikeluarkan melalui output berupa piezzo super tweeter. Rangkaian ultrasonik ini dirancang untuk menghasilkan beberapa frekuensi ultrasonik yakni: $40 \mathrm{KHz}, 50 \mathrm{KHz}$, dan $60 \mathrm{KHz}$ dengan sumber tegangan 5 volt dari adaptor.

Setelah melakukan perancangan dan perakitan alat maka dilakukan pengujian frekuensi output yang dihasilkan. Pengujian ketepatan alat ini bertujuan untuk mengetahui presisi output frekuensi yang dihasilkan alat ini.

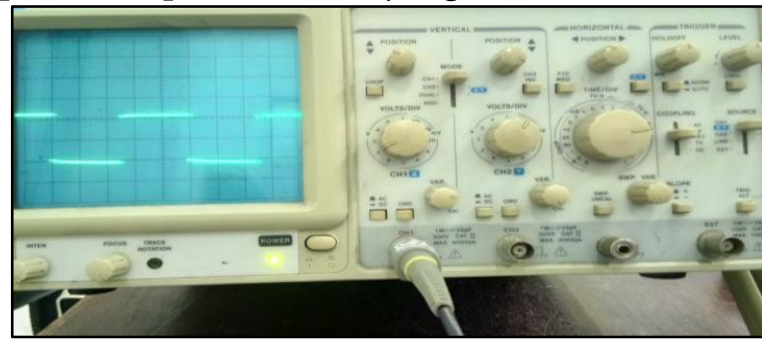

Gambar 6. Pengukuran frekuensi $40 \mathrm{KHz}$ pada osiloskop

Berdasarkan gambar 6 diatas, hasil pengukuran osiloskop menunjukkan satu periode tepat pada garis keempat dalam satu kotak sumbu $\mathrm{x}$, dengan time $/$ div $5 \mu \mathrm{s}$, maka periode $=5 \mathrm{x} 5 \mathrm{x} 1$ sama dengan $25 \mu$ s. Hubungan periode dangan frekuensi dapat diambil dari persamaan: $\mathrm{T}=1 / \mathrm{f}$ dimana $\mathrm{T}=25 \mu \mathrm{s}$, maka frekuensi sama dengan $1 / T$. Nilai frekuensi yang di dapat dari osiloskop sesuai dengan yang diharapkan sebesar $40 \mathrm{KHz}$. Persentasi kesalahan 0\%. Nilai amplitudonya adalah tinggi 1 gelombang $\mathrm{x}$ volt/div $\mathrm{x}$ probe, nilainya $=2 \operatorname{div} \times 2$ volt $/$ div $\mathrm{x} 1$ sama dengan 4 volt

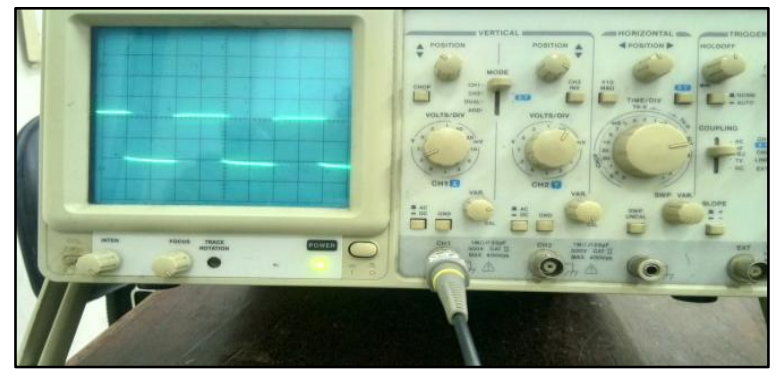

Gambar 7. Pengukuran frekuensi $50 \mathrm{KHz}$ pada osiloskop

Berdasarkan gambar 7 ini merupa-kan hasil pengukuran osiloskop menun-jukkan satu periode berada pada 4 kotak sumbu $\mathrm{x}$ dengan time/ div osiloskop pada $5 \mu$ s. Maka periode $=4 \mathrm{x}$ 5 x 1 sama dengan $20 \mu$ s. Hubungan periode dangan frekuensi dapat diambil dari persamaan: $\mathrm{T}=1 / \mathrm{f}$ dimana $\mathrm{T}=20 \mu \mathrm{s}$, maka frekuensi sama dengan 1/T. Nilai frekuensi yang di dapat dari osiloskop sesuai dengan yang diharapkan sebesar $50 \mathrm{KHz}$. Persentasi kesalahan 0\%. Nilai amplitudonya adalah tinggi 1 gelombang $\mathrm{x}$ volt/div $\mathrm{x}$ probe, nilainya $=2 \operatorname{div} \mathrm{x} 2$ volt/div $\mathrm{x} 1$ sama dengan 4 volt

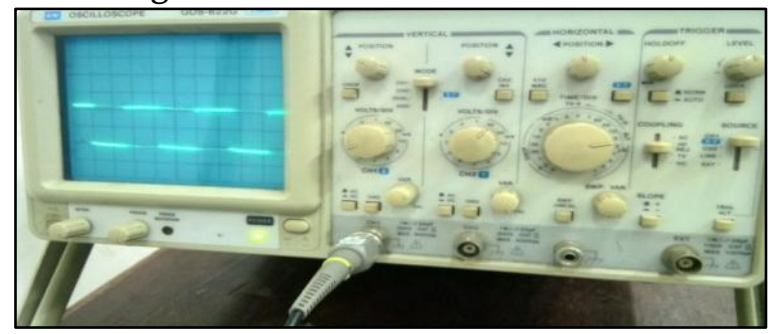

Gambar 8. Pengukuran frekuensi $60 \mathrm{KHz}$ pada osiloskop

Berdasarkan gambar 8 ini meru-pakan hasil pengukuran osiloskop menun-jukkan satu periode pada 3,4 kotak pada sumbu $\mathrm{x}$ dengan time/ div osiloskop pada $5 \mu$ s. Maka periode $=3,2$ x 5 x 1 sama dengan $16 \mu$ s. Hubungan periode dengan frekuensi dapat diambil dari persamaan: $\mathrm{T}=1 / \mathrm{f}$ dimana $\mathrm{T}=16 \mu \mathrm{s}$, maka frekuensi sama dengan $1 / \mathrm{T}$. Nilai frekuensi yang di dapat dari osiloskop sebesar 62,5 KHz. Persentase 
kesalahannya 9.6\%. Hal ini terjadi karena skala division pada osilokop analog berskala minimum 0 . 2 div, sehingga pengukuran terbaca $62,5 \mathrm{KHz}$. Nilai amplitudonya adalah tinggi 1 gelombang $\mathrm{x}$ volt/div $\mathrm{x}$ probe, nilainya $=2 \operatorname{div} \mathrm{x} 2 \mathrm{volt} / \mathrm{div} \mathrm{x} 1$ sama dengan 4 volt

Grafik karakteristik respon tikus terhadap gelombang ultrasonik.

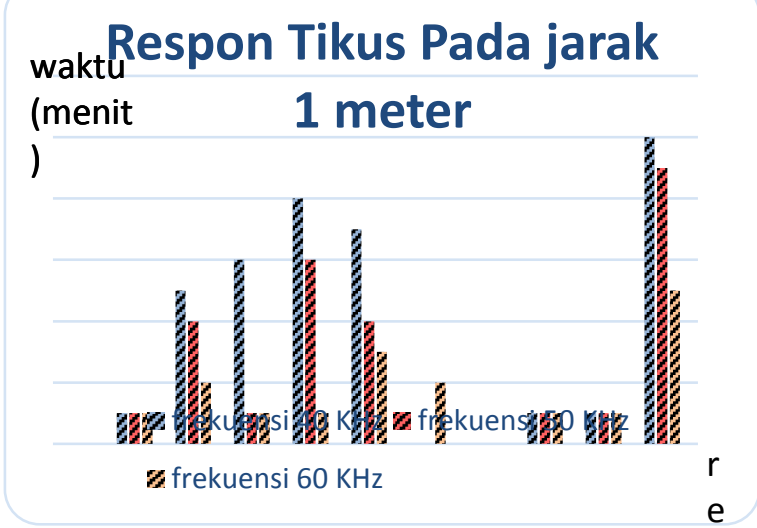

Gambar 9. Grafik pengaruh frekuensi terhadap tikus pada jarak 1 meter

Respon Tikus Pada jarak 2 meter
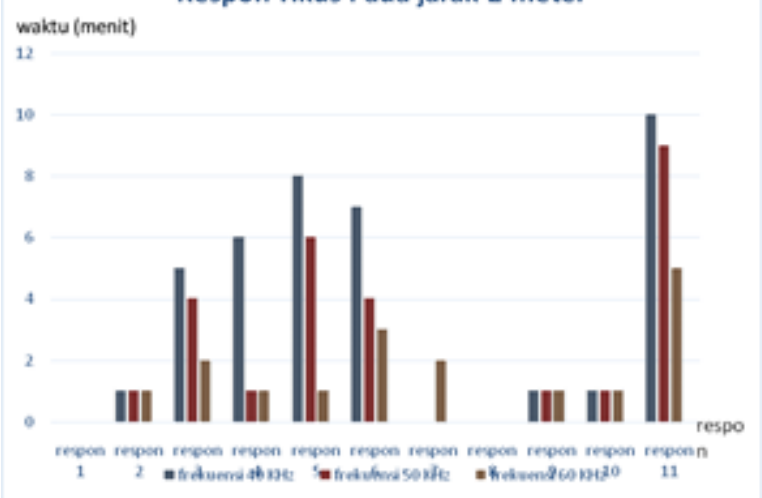

Gambar 10. Grafik pengaruh frekuensi terhadap tikus pada jarak 2 meter

Respon tikus saat dipancarkan gelombang ultrasonik pada grafik di beri inisial respon 1-11. Makna inisial respon tikus ini akan ditunjukan pada tabel 4.1.

Tabel 4.1. Makna inisialisasi respon tikus

\begin{tabular}{|c|c|c|}
\hline No & Inisialisasi & Makna \\
\hline 1 & Respon 1 & Diam \\
\hline 2 & Respon 2 & $\begin{array}{c}\text { Gerak langkah kaki } \\
\text { pelan }\end{array}$ \\
\hline 3 & Respon 3 & $\begin{array}{c}\text { Gerak langkah kaki } \\
\text { semakin cepat }\end{array}$ \\
\hline 4 & Respon 4 & $\begin{array}{c}\text { Gerak mulut menjilati } \\
\text { tubuh }\end{array}$ \\
\hline
\end{tabular}

\begin{tabular}{|c|c|c|}
\hline 5 & Respon 5 & $\begin{array}{c}\text { Gerak mencakar kepala } \\
\text { dan kuping }\end{array}$ \\
\hline 6 & Respon 6 & $\begin{array}{c}\text { Gerak kaki memanjat- } \\
\text { manjat }\end{array}$ \\
\hline 7 & Respon 7 & $\begin{array}{c}\text { Gerak kepala bergetar } \\
\text { (terkejut) }\end{array}$ \\
\hline 8 & Respon 8 & Gerak pupil mata besar \\
\hline 9 & Respon 9 & $\begin{array}{c}\text { Gerak pupil mata } \\
\text { mengecil }\end{array}$ \\
\hline 10 & Respon 10 & Gerak mulut bergetar \\
\hline 11 & Respon 11 & $\begin{array}{r}\text { Tubuh bagian perut } \\
\text { bergetar }\end{array}$ \\
\hline
\end{tabular}

Berdasarkan gambar 6 (frekuensi 40 $\mathrm{KHz}$ ), 7 (frekuensi $50 \mathrm{KHz}$ ), dan 8 (frekuensi 60 $\mathrm{KHz}$ ), memiliki amplitudo yang sama sebesar 4 volt di osiloskop. Demikian juga pada gambar 4.5 dan 4.6 menunjukan respon tikus yang sama. Berdasarkan informasi variasi frekuensi dan amplitudo tegangan konstan terhadap respon tikus yang tetap, diperlukan perubahan amplitudo tegangan agar berubah respon tikus.

\section{KESIMPULAN DAN SARAN}

Dari hasil penelitian, dapat disimpulkan bahwa:

1. Alat ini dapat menjangkau jarak maksimal 2 meter untuk kategori efektif mengusik tikus

2. Tikus pada jarak 2 meter frekuensi 40,50 , dan $60 \mathrm{KHz}$ masih bisa mempengaruhi tikus. Tetapi jika dikaji lebih dalam frekuensi paling efektif adalah frekuensi $60 \mathrm{KHz}$.

3. Piezzo super tweeter sangat bermanfaat pada alat ini, dikarenakan mampu mengeluarkan suara dengan frekuensi ultrasonik

\section{DAFTAR PUSTAKA}

Komariah, S., Tan, M., ( 2010 ), Pengendalian Vektor, Jurnal Kesehatan Bina Husada : Vol 6 No 1

Soemarno, (2010), Manajemen Argo ekosistem, malang: PPSUB.

Heffner, H., E., Heffner, R, S., (2007), Hearing Ranges of Laboratory Animals, Journal of the American Association for 
Laboratory Animal Science: Vol 46,No1

Sudjanarko, S, danYudhi, L., (2012), Studi Parameter Fisik Tanah dengan Gelombang Ultrasonik.Prosiding Seminar Nasional Aplikasi Teknologi Prasarana Wilayah (ATPW):2301-6752

Septaji, Handayani W.2015. mudah belajar mikrokontroler dengan arduino. Bandung : widya media International Standard ISO 2631-1, Second edition, 1997-05-01, Amendment 1 2010-0701.

Hermanto, D., Fadillah, N. I., (2014 ), Pembuatan Gelang Ultrasonik Untuk Alat Bantu Mobilitas Tunanetra Menggunakan Mikrokontroler Atmega8, Jurnal Evolusi: Vol II No 2 